\title{
Rhinovirus infection has allergen-specific tolerance-breaking effects on PBMCs of healthy individuals
}

\author{
Umut Can Kucuksezer ${ }^{1,2 *}$, Alar Aab², Beate Rueckert ${ }^{2}$, Gunnur Deniz ${ }^{1}$, Cezmi Akdis², Mübeccel Akdis² \\ From 3rd WAO International Scientific Conference (WISC) 2014 \\ Rio de Janeiro, Brazil. 6-9 December 2014
}

\section{Background}

Allergen-specific $\mathrm{T}$ cell tolerance is important in healthy immune responses to environmental allergens, mechanisms of loss of tolerance to allergens is still not completely understood. Studies investigating maintenance and breaking of peripheral $\mathrm{T}$ cell responsiveness clearly showed the contribution of inflammatory cytokines and triggering of TLR4 and TLR8 to loss of unresponsiveness to allergens. Human rhinoviruses are most common viral infective agents in humans and the predominant cause of cold. The primary route of entry is the upper respiratory tract. Upon infection, virus replicates, spreads and cause infected cells to release chemokines and cytokines. Rhinovirus infections are known to be associated with an increased risk of asthma development, and among children with prevalent asthma, $85 \%$ of asthma exacerbations are associated with viral infections. However, the exact nature of this relationship remains unclear.

\section{Methods}

PBMCs of healthy individuals with known healthy responses to allergens were incubated with Rhinovirus $1 \mathrm{~B}$ and 16 strains, with increasing doses with the absence or existence of allergens in cell-culture conditions. On day +5 , cell proliferation was investigated with (3H)-thymidine incorporation or CFSE dilution methods. Rhinovirus strains were produced upon infection with HELA cells and culture supernatants containing alive rhinovirus was used in cultures. TCID50 of viral infection was evaluated and dilutions in PBMCs were made according to this value.

${ }^{1}$ Istanbul University, Institute of Experimental Medicine (DETAE), Turkey Full list of author information is available at the end of the article

\section{Results}

Our results demonstrate the allergen-specific $\mathrm{T}$ cell tolerance-breaking effects of both strains in different virus doses.

\section{Conclusion}

More detailed studies are needed to clarify molecular mechanisms for breaking of allergen-specific unresponsiveness by rhinovirus infection.

\section{Authors' details}

Istanbul University, Institute of Experimental Medicine (DETAE), Turkey.

${ }^{2}$ Swiss Institute of Allergy and Asthma Research (SIAF), Switzerland.

Published: 8 April 2015

doi:10.1186/1939-4551-8-S1-A257

Cite this article as: Kucuksezer et al:: Rhinovirus infection has allergenspecific tolerance-breaking effects on PBMCs of healthy individuals. World Allergy Organization Journal 2015 8(Suppl 1):A257.

Submit your next manuscript to BioMed Central and take full advantage of:

- Convenient online submission

- Thorough peer review

- No space constraints or color figure charges

- Immediate publication on acceptance

- Inclusion in PubMed, CAS, Scopus and Google Scholar

- Research which is freely available for redistribution

Submit your manuscript at www.biomedcentral.com/submit 